\title{
Abundance of Entomopathogenic Fungi in Leaf Litter and Soil Layers in Forested Habitats in Poland
}

\author{
Anna Majchrowska-Safaryan * and Cezary Tkaczuk \\ Faculty of Agrobioengineering and Animal Husbandry, Institute of Agriculture and Horticulture, \\ Siedlce University of Natural Sciences and Humanities, 08-110 Siedlce, Poland; cezary.tkaczuk@uph.edu.pl \\ * Correspondence: anna.majchrowska-safaryan@uph.edu.pl
}

check for updates

Citation: Majchrowska-Safaryan,

A.; Tkaczuk, C. Abundance of

Entomopathogenic Fungi in Leaf Litter and Soil Layers in Forested Habitats in Poland. Insects 2021, 12, 134. https://doi.org/10.3390/ insects12020134

Academic Editors: Eustachio Tarasco and Francesca De Luca

Received: 14 December 2020

Accepted: 1 February 2021

Published: 5 February 2021

Publisher's Note: MDPI stays neutral with regard to jurisdictional claims in published maps and institutional affiliations.

Copyright: (c) 2021 by the authors. Licensee MDPI, Basel, Switzerland. This article is an open access article distributed under the terms and conditions of the Creative Commons Attribution (CC BY) license (https:// creativecommons.org/licenses/by/ $4.0 /)$.
Simple Summary: The soil environment is an important reservoir for a wide variety of entomopathogenic fungi that can suppress insect populations, including agricultural and forestry pests. This research aims to investigate the species composition and density of entomopathogenic fungi $(\mathrm{EPF})$ in the leaf litter and at different soil depths in different types of forests during different seasons (spring, autumn). The current study describes the density of four different genera of entomopathogenic fungi in forest soils and leaf litter. The densities of EPF were usually higher in leaf litter than soil, and Beauveria spp. were the most prevalent fungi among leaf litter and soil samples compared to other entomopathogenic fungi. This research will give new insights into our understanding of EPF diversity and composition in forests.

Abstract: This study aims to determine the species composition and density of colony-forming units (CFU) of entomopathogenic fungi (EPF) in leaf litter at different depths of the top layer of forest soils depending on the type of forest (coniferous, deciduous and mixed forest), and the date of sampling (spring, autumn). In each type of forest, leaf litter and soil were collected using a soil stick from four depths of soil: $0-5,5-10,10-15$ and 15-20 cm. Entomopathogenic fungi were isolated by a soil or litter dilution plating method on a selective medium. Four fungal genera were found: Beauveria spp., Cordyceps spp., Metarhizium spp., and Lecanicillium spp. The density of EPF was usually higher in leaf litter than in the layers of soil below, and the most frequently isolated species from both environments were Beauveria spp. among soil samples from all forest types; Beauveria spp. were most abundant in the top layer $(0-5 \mathrm{~cm})$, and their density of CFUs gradually decreased deeper into the soil profile.

Keywords: insect-pathogenic fungi; Hypocreales; Beauveria; colony-forming units; habitat preference

\section{Introduction}

Forests cover over $29 \%$ of Poland's territory [1]. The stands are dominated mainly by conifers, including Pinus sylvestris L., which covers about $60 \%$ of forest areas [2]. The predominance of coniferous stands results in favourable conditions for the development and gradation of pests in single-species and equal-age forests growing in poor and degraded habitats [3]. It is believed that over $65 \%$ of Poland's biological resources are concentrated in forest ecosystems. One of the characteristic features of soil is its biological activity, shaped by a number of microorganisms, including entomopathogenic fungi (EPF) $[4,5]$.

The soil environment is an important reservoir for a wide variety of EPF that can make an important contribution to the control of insect populations, including agricultural and forestry pests [6]. The occurrence and distribution of EPF in soils of various environments have been the subject of numerous studies in many countries [4,7-11]. Many species of Hypocrealean (Ascomycota) fungi live in the soil for most of their life cycle. Among these fungi, Beauveria spp., Metarhizium spp., Cordyceps spp. and Lecanicillium spp. are common genera found in agricultural and forest soils and have the greatest potential for biological control $[12,13]$. These fungi form a specialised group of natural enemies that can infect 
host populations on a large scale and lead to epizootics [14,15]. Entomopathogenic fungi inhabiting the soil environment are important bioregulators not only of typical soil pests but also of a large group of pests of agricultural and forestry crops that descend into the soil for periodic diapause, pupation or wintering. It is estimated that about $90 \%$ of herbivorous pests spend at least part of their development cycle in the soil [16]. Arthropod hosts are killed by EPF and, with fungal outgrowth, provide inocula that can spread to other susceptible hosts in the soil environment, e.g., horizontal transmission. According to Bałazy [17], the soils of seminatural environments constitute an important reservoir of EPF populations in the natural landscape, from which they can spread into the habitats of cultivated fields and meadows. Entomopathogenic fungi provide an invaluable service of suppressing pest populations and preventing pest outbreaks in forest habitats $[14,18-20]$.

Identifying native strains of EPF and studying their population densities (CFUs) and patterns of occurrence in forest leaf litter and the soil environment may provide insights into the biodiversity of naturally occurring fungi and may expand the pool of potential species used in biological control [21].

Therefore, this study aims to determine the species composition and intensity of EPF occurrence in leaf litter and soils in selected forested habitats in Poland.

\section{Materials and Methods}

\subsection{Research Location}

The material for the study consisted of leaf litter and forest soils collected between 2015 and 2017 from the areas of the State Forests, Siedlce Forest District, Masovian Voivodeship, Poland, in the villages of Golice (geographical coordinates $52^{\circ} 12^{\prime} 15^{\prime \prime} \mathrm{N}$ and $22^{\circ} 20^{\prime} 32^{\prime \prime} \mathrm{E}$ ) and Chodów (geographical coordinates $52^{\circ} 12^{\prime} 42^{\prime \prime} \mathrm{N}$ and $22^{\circ} 14^{\prime} 05^{\prime \prime} \mathrm{E}$ ), located approximately $10 \mathrm{~km}$ from each other (Figure S1). In the years of sampling for research, different weather conditions prevailed (Table S1).

Samples for research were collected at two localities in time: autumn (I-2015, III-2016 October) and spring (II-2016, IV-2017 May). In each of them, in the forest complex, three types of forest habitats were selected (coniferous, deciduous and mixed forests), with an area of about 10 hectares each. The first type of forest was represented by coniferous pine forests, the second by deciduous forests with a predominance of oak, and the third was a mixed forest with a predominance of deciduous trees. The forests in Golice and Chodów were about 50 and 40 years old, respectively. In each type of forest, leaf litter and soil were collected using a soil stick (Ø $30 \mathrm{~mm}$ ) from four layers: 0-5, 5-10, 10-15 and 15-20 cm. At each site, leaf litter and soil were collected from 15 randomly selected sites, including a minimum distance of $10 \mathrm{~m}$ between them. The soil stick was cleaned with $70 \%$ ethanol between sampling points. A mixed sample was prepared from the samples collected in this way (in total, $200 \mathrm{~g}$ of leaf litter and $300 \mathrm{~g}$ of soil from each layer was taken from each forest type and location) and stored in plastic bags at the temperature of $0-4^{\circ} \mathrm{C}$.

\subsection{Soil Analysis}

In the collected material, selected chemical properties were determined in the laboratory of the Regional Chemical and Agricultural Station in Warsaw in accordance with the applicable standards and procedures: $\mathrm{pH}$ of soil and leaf litter using the potentiometric method in $1 \mathrm{~mol} \mathrm{KCl}$; organic matter content in the leaf litter-by weighted method, after drying at $105^{\circ} \mathrm{C}$ and burning the analysed material in a muffle furnace at $550^{\circ} \mathrm{C}$ (Table S2).

\subsection{Fungi Isolation}

EPF from leaf litter and individual layers of soil to a depth of $20 \mathrm{~cm}$ were isolated by sowing on a selective culture medium developed by Strasser et al. [22]. This is a commonly used method for the isolation of entomopathogenic fungi from soil [9,23-26] and leaf litter environments [27] and is particularly useful when quantification is necessary. The selective medium was composed of $20 \mathrm{~g}$ of glucose (Biomus, Białystok, Poland), $10 \mathrm{~g}$ of peptone (Becton, Dickinson and Company, Le Pont de Claix, France) and $18 \mathrm{~g}$ of agar (Sigma, 
St. Louis, MI, USA), which were dissolved in $1 \mathrm{~L}$ of deionised water, and then sterilised in an autoclave at $120^{\circ} \mathrm{C}$ for $20 \mathrm{~min}$. The following selective components were added to the medium after it cooled to $50{ }^{\circ} \mathrm{C}: 0.6 \mathrm{~g}$ of streptomycin (Serva, Heidelberg, Germany), $0.05 \mathrm{~g}$ of tetracycline (Sigma, St. Louis, MO, USA), $0.05 \mathrm{~g}$ of cycloheximide (Sigma, St. Louis, MO, USA), and $0.1 \mathrm{~g}$ of dodine (Arysta LifeScience, Seraing, Belgium). For each mixed sample of leaf litter or layer of soil, $2 \mathrm{~g}$ of soil or leaf litter were mixed with $18 \mathrm{~mL}$ of $0.05 \%$ nonsterilised Triton-X (Sigma, St. Louis, MO, USA). Using an automatic pipette, soil solutions prepared in the amount of $0.1 \mathrm{~mL}$ were placed on the surface of the selective substrate and spread with the use of a glass spatula. Petri dishes $(90 \mathrm{~mm}$, Noex, Komorniki, Poland) were placed in incubators at $22{ }^{\circ} \mathrm{C}$, and, after 8-10 days, the colonies of fungi were counted. We used three replicates of selective medium for each sample. The results are expressed as the number of CFUs of each genera of entomopathogenic fungi in $1 \mathrm{~g}$ of dry leaf litter or soil.

The in-vitro fungal cultures were microscopically identified according to the morphology of the microstructures [28-31]. Characterisation of fungal isolates was made by the determination of conidial size and shape, conidiogenous cell, and colony morphology. Given that only morphological methods were applied during the identification of fungi, they were described to the rank of genus, because, as demonstrated by the latest phylogenetic studies based on DNA sequencing [29,32-34], there are numerous fungus species within the genus of Beauveria, Cordyceps, Metarhizium and Lecanicillium that are almost impossible to distinguish from each other without the application of molecular methods.

\subsection{Statistical Analysis}

The obtained results were statistically processed using the Statistica program v. 13.3 (TIBCO Software Inc, Palo Alto, CA, USA). The first stage of the analysis was to check with the chi-square $\lambda^{2}$ test-whether the distribution of the tested trait (number of CFUs) in the sample followed a normal distribution. Since the data did not have a normal distribution, the transformation $y=\log (x+0.5)$ was applied. Then, on the transformed data, one-way ANOVA analysis was performed for each factor separately according to the following model:

$$
\mathrm{y}_{\mathrm{ij}}=\mathrm{m}+\mathrm{a}_{\mathrm{i}}+\mathrm{e}_{\mathrm{ij}} ;
$$

where $\mathrm{m}$ is the population average; $\mathrm{y}_{\mathrm{ij}}$ is the value of the examined trait (number of CFUs); $a_{i}$ is the effect of the $i$-th level of factor A (sampling date, type of forest, sampling depth); $\mathrm{e}_{\mathrm{ij}}$ is the random error.

When the factor's effect was significant, the Tukey test was used at $p \leq 0.05$ to compare the means (posthoc analysis).

\section{Results}

In the samples of leaf litter and soil, the presence of four genera of EPF was found: Beauveria spp., Cordyceps spp., Metarhizium spp., and Lecanicillium spp. (Tables 1 and 2). 
Table 1. Mean densities of entomopathogenic fungi (CFUs $\times 10^{3} / \mathrm{g}$ soil or leaf litter) from the Golice locality; lowercase letters represent statistically significant differences between CFUs among the sampling depths (leaf litter vs. other layers) at each sampling date and forest type.

\begin{tabular}{|c|c|c|c|c|c|c|c|c|c|c|c|c|c|c|c|c|c|}
\hline \multirow{4}{*}{ ڤ્. } & \multirow{4}{*}{ 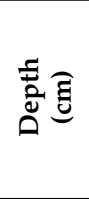 } & \multicolumn{16}{|c|}{ Entomopathogenic Fungi } \\
\hline & & \multicolumn{4}{|c|}{ Beauveria spp. } & \multicolumn{4}{|c|}{ Cordyceps spp. } & \multicolumn{4}{|c|}{ Metarhizium spp. } & \multicolumn{4}{|c|}{ Lecanicillium spp. } \\
\hline & & \multicolumn{16}{|c|}{ Sample Collection Date } \\
\hline & & $\mathbf{I}$ & II & III & IV & $\mathbf{I}$ & II & III & IV & I & II & III & IV & I & II & III & IV \\
\hline \multirow{5}{*}{ 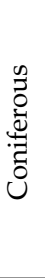 } & ${ }^{*}$ L. 1 & $3.5 \mathrm{a}$ & $6.7 \mathrm{a}$ & $7.7 \mathrm{a}$ & $8.2 \mathrm{a}$ & 0 & 0 & 0 & 0 & $0 \mathrm{~d}$ & $0.2 \mathrm{~d}$ & $0 \mathrm{c}$ & $0 \mathrm{c}$ & $2.2 \mathrm{a}$ & $0.7 \mathrm{a}$ & $0.8 \mathrm{a}$ & $1.2 \mathrm{a}$ \\
\hline & $0-5$ & $0.7 \mathrm{~b}$ & $5.3 \mathrm{a}$ & $5.2 \mathrm{~b}$ & $8.8 \mathrm{a}$ & 0 & 0 & 0 & 0 & $28.8 \mathrm{a}$ & $\begin{array}{c}11.5 \\
\mathrm{a}\end{array}$ & $0.2 \mathrm{c}$ & $2.3 \mathrm{a}$ & $0 \mathrm{~b}$ & $0.6 \mathrm{a}$ & $0.8 \mathrm{a}$ & $0.3 \mathrm{~b}$ \\
\hline & $5-10$ & $0.5 \mathrm{~b}$ & $2.3 \mathrm{~b}$ & $4.2 \mathrm{~b}$ & $8.5 \mathrm{a}$ & 0 & 0 & 0 & 0 & $9.2 \mathrm{~b}$ & $8.7 \mathrm{~b}$ & $4.0 \mathrm{~b}$ & $\begin{array}{l}0.3 \\
\text { bc }\end{array}$ & $0 \mathrm{~b}$ & $\begin{array}{l}0.5 \\
a b\end{array}$ & $\begin{array}{l}0.5 \\
a b\end{array}$ & $0.2 \mathrm{~b}$ \\
\hline & $10-15$ & $0.3 \mathrm{~b}$ & $1.8 \mathrm{~b}$ & $2.5 \mathrm{c}$ & $6.7 \mathrm{~b}$ & 0 & 0 & 0 & 0 & $4.3 \mathrm{c}$ & $7.1 \mathrm{~b}$ & $1.0 \mathrm{c}$ & $0.5 \mathrm{~b}$ & $0 \mathrm{~b}$ & $0.2 \mathrm{~b}$ & $0.2 \mathrm{~b}$ & $\begin{array}{l}0.8 \\
a b\end{array}$ \\
\hline & $15-20$ & $0.2 \mathrm{~b}$ & $0.5 \mathrm{c}$ & $0.8 \mathrm{~d}$ & $6.8 \mathrm{~b}$ & 0 & 0 & 0 & 0 & $3.5 \mathrm{c}$ & $2.8 \mathrm{c}$ & $7.3 \mathrm{a}$ & $0.5 \mathrm{~b}$ & $0 \mathrm{~b}$ & $0.2 \mathrm{~b}$ & $0.2 \mathrm{~b}$ & $0.3 \mathrm{~b}$ \\
\hline \multirow{5}{*}{ 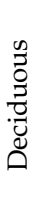 } & L. 1 & $2.2 \mathrm{~b}$ & $4.7 \mathrm{a}$ & $9.5 \mathrm{a}$ & $9.8 \mathrm{a}$ & 0 & $0 \mathrm{c}$ & 0 & 0 & $3.0 \mathrm{a}$ & 0 & 0 & 0 & $0.3 \mathrm{c}$ & 1.0 & 0.5 & 0.8 \\
\hline & $0-5$ & $3.0 \mathrm{a}$ & $4.3 \mathrm{a}$ & $3.5 \mathrm{~b}$ & $3.7 \mathrm{~b}$ & 0.2 & $2.3 \mathrm{a}$ & 0.7 & 0 & $0.3 \mathrm{~b}$ & 0 & 0 & 0.5 & $2.1 \mathrm{a}$ & 0.7 & 1.3 & 1.0 \\
\hline & $5-10$ & $\begin{array}{l}1.7 \\
\mathrm{ab}\end{array}$ & $2.3 \mathrm{~b}$ & $3.3 \mathrm{~b}$ & $2.8 \mathrm{~b}$ & 0 & $0.2 \mathrm{c}$ & 0.2 & 0 & $0.2 \mathrm{~b}$ & 0 & 0 & 0 & $1.8 \mathrm{ab}$ & 0.8 & 0.8 & 0.8 \\
\hline & 10-15 & $0.3 \mathrm{c}$ & $1.5 \mathrm{bc}$ & $3.2 \mathrm{~b}$ & $3.3 \mathrm{~b}$ & 0 & $1.5 \mathrm{~b}$ & 0.3 & 0 & $0.2 \mathrm{~b}$ & 0 & 0 & 0 & $1.3 \mathrm{~b}$ & 0.5 & 0.8 & 0.8 \\
\hline & $15-20$ & $0.2 \mathrm{c}$ & $0.8 \mathrm{c}$ & $2.2 \mathrm{~b}$ & $1.5 \mathrm{c}$ & 0.3 & $0 \mathrm{c}$ & 0.7 & 0 & $0 \mathrm{~b}$ & 0 & 0 & 0 & $0 \mathrm{c}$ & 0.7 & 0.8 & 0.5 \\
\hline \multirow{5}{*}{ 离 } & L. 1 & $2.3 \mathrm{a}$ & $7.5 \mathrm{a}$ & $9.8 \mathrm{a}$ & $10.0 \mathrm{a}$ & 0 & 0 & 0 & 0 & 0 & 0 & 0 & 0 & $0.7 \mathrm{ab}$ & $0.8 \mathrm{a}$ & 1.5 & 1.2 \\
\hline & $0-5$ & $1.5 \mathrm{~b}$ & $2.0 \mathrm{~b}$ & $4.3 \mathrm{~b}$ & $3.7 \mathrm{~b}$ & 0.2 & 0 & 0.5 & 0 & 0 & 0 & 0 & 0 & $1.6 \mathrm{a}$ & $0.7 \mathrm{a}$ & 0.8 & 1.3 \\
\hline & 5-10 & $0.6 \mathrm{c}$ & $0.7 \mathrm{c}$ & $3.2 \mathrm{~b}$ & $3.0 \mathrm{bc}$ & 0 & 0 & 0 & 0.2 & 0 & 0 & 0 & 0 & $1.4 \mathrm{a}$ & $\begin{array}{l}0.5 \\
a b\end{array}$ & 1.3 & 1.5 \\
\hline & 10-15 & $1.0 \mathrm{~b}$ & $0.3 \mathrm{~cd}$ & $2.3 \mathrm{c}$ & $2.5 \mathrm{c}$ & 0 & 0 & 0.2 & 0 & 0 & 0 & 0 & 0 & $0.8 \mathrm{ab}$ & $\begin{array}{l}0.2 \\
b c\end{array}$ & 0.7 & 0.7 \\
\hline & $15-20$ & $0.3 \mathrm{c}$ & $0 \mathrm{~d}$ & $1.0 \mathrm{c}$ & $2.0 \mathrm{c}$ & 0 & 0 & 0 & 0 & 0 & 0 & 0 & 0 & $0.5 \mathrm{~b}$ & $0 \mathrm{c}$ & 0.7 & 1.2 \\
\hline
\end{tabular}

I—autumn 2015; II—spring 2016; III—autumn 2016; IV—spring 2017; *L. l—leaf litter.

Table 2. Mean densities of entomopathogenic fungi (CFUs $\times 10^{3} / \mathrm{g}$ soil or leaf litter) in the Chodów locality; lowercase letters represent statistically significant differences between CFUs among the sampling depths (leaf litter vs. other layers) at each sampling date and forest type.

\begin{tabular}{|c|c|c|c|c|c|c|c|c|c|c|c|c|c|c|c|c|c|}
\hline \multirow{4}{*}{$\stackrel{0}{\stackrel{2}{2}}$} & \multirow{4}{*}{ 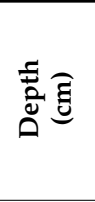 } & \multicolumn{16}{|c|}{ Entomopathogenic Fungi } \\
\hline & & \multicolumn{4}{|c|}{ Beauveria spp. } & \multicolumn{4}{|c|}{ Cordyceps spp. } & \multicolumn{4}{|c|}{ Metarhizium spp. } & \multicolumn{4}{|c|}{ Lecanicillium spp. } \\
\hline & & \multicolumn{16}{|c|}{ Sample Collection Date } \\
\hline & & I & II & III & IV & I & II & III & IV & $\mathbf{I}$ & II & III & IV & I & II & III & IV \\
\hline \multirow{5}{*}{ 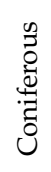 } & ${ }^{*}$ L. 1 & $7.7 \mathrm{a}$ & $2.7 \mathrm{~b}$ & $8.0 \mathrm{a}$ & $11.8 \mathrm{a}$ & 0 & 0 & 0 & 0 & 0 & 0 & 0 & 0 & $4.8 \mathrm{a}$ & 0.3 & $2.0 \mathrm{a}$ & 1.3 \\
\hline & $0-5$ & $0.5 \mathrm{~b}$ & $5.5 \mathrm{a}$ & $3.2 \mathrm{~b}$ & $5.0 \mathrm{~b}$ & 0 & 0 & 0 & 0 & 0 & 0 & 0 & 0 & $0 \mathrm{~b}$ & 0.8 & $1.5 \mathrm{~b}$ & 0.8 \\
\hline & $5-10$ & $0.3 \mathrm{~b}$ & $3.2 \mathrm{ab}$ & $1.3 \mathrm{c}$ & $4.6 \mathrm{bc}$ & 0 & 0 & 0 & 0 & 0 & 0 & 0 & 0 & $0 \mathrm{~b}$ & 0.5 & $0.7 \mathrm{c}$ & 0.8 \\
\hline & $10-15$ & $0.2 \mathrm{~b}$ & $2.3 \mathrm{~b}$ & $0.5 \mathrm{~d}$ & $2.3 \mathrm{bc}$ & 0 & 0 & 0 & 0 & 0 & 0 & 0 & 0 & $0 \mathrm{~b}$ & 0.3 & $0.3 c$ & 1.2 \\
\hline & $15-20$ & $0.2 \mathrm{~b}$ & $0.3 \mathrm{c}$ & $0.3 \mathrm{~d}$ & $2.5 \mathrm{bc}$ & 0 & 0 & 0 & 0 & 0 & 0 & 0 & 0 & $0 \mathrm{~b}$ & 0.2 & $0.2 \mathrm{c}$ & 1.0 \\
\hline \multirow{5}{*}{ 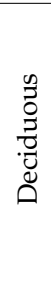 } & L. 1 & $4.3 \mathrm{a}$ & $2.2 \mathrm{~b}$ & $9.5 \mathrm{a}$ & $13.2 \mathrm{a}$ & 0 & 0 & 0 & $0.2 \mathrm{~b}$ & $0 \mathrm{~d}$ & 0 & $0 \mathrm{~b}$ & $0.2 \mathrm{c}$ & $1.2 \mathrm{bc}$ & $0 \mathrm{c}$ & $2.2 \mathrm{a}$ & $1.2 \mathrm{a}$ \\
\hline & $0-5$ & $0.7 \mathrm{~b}$ & $3.7 \mathrm{a}$ & $9.0 \mathrm{a}$ & $2.0 \mathrm{~b}$ & 0.2 & 0.3 & 0 & $6.3 \mathrm{a}$ & $2.8 \mathrm{c}$ & 0 & $\begin{array}{l}1.0 \\
a b\end{array}$ & $0 \mathrm{c}$ & $4.3 \mathrm{a}$ & $0 \mathrm{c}$ & $2.2 \mathrm{a}$ & $0 \mathrm{~b}$ \\
\hline & $5-10$ & $0.5 \mathrm{~b}$ & $1.7 \mathrm{bc}$ & $4.0 \mathrm{~b}$ & $1.0 \mathrm{~b}$ & 0 & 0.2 & 1.0 & $0.2 \mathrm{~b}$ & $4.3 \mathrm{~b}$ & 0 & $1.5 \mathrm{a}$ & $\begin{array}{c}11.8 \\
\mathrm{a}\end{array}$ & $1.8 \mathrm{bc}$ & $0.5 \mathrm{~b}$ & $\begin{array}{l}1.7 \\
a b\end{array}$ & $1.7 \mathrm{a}$ \\
\hline & 10-15 & $0.5 \mathrm{~b}$ & $0.7 \mathrm{c}$ & $1.7 \mathrm{c}$ & $1.5 \mathrm{~b}$ & 0 & 0.2 & 0 & $0.3 \mathrm{~b}$ & $6.0 \mathrm{a}$ & 0 & 0.5 & $0 \mathrm{c}$ & $2.0 \mathrm{~b}$ & $0.3 \mathrm{~b}$ & $0.8 \mathrm{~b}$ & $0 \mathrm{~b}$ \\
\hline & $15-20$ & $0.2 \mathrm{~b}$ & $0.5 \mathrm{c}$ & $1.3 \mathrm{c}$ & $1.8 \mathrm{~b}$ & 0 & 0 & 0 & $0.7 \mathrm{~b}$ & $5.3 \mathrm{ab}$ & 0 & $0.2 \mathrm{~b}$ & $3.2 \mathrm{~b}$ & $1.0 \mathrm{c}$ & $1.0 \mathrm{a}$ & $0.7 \mathrm{~b}$ & $0 \mathrm{~b}$ \\
\hline \multirow{5}{*}{ 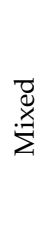 } & L. 1 & $8.0 \mathrm{a}$ & $2.5 \mathrm{a}$ & $5.5 \mathrm{a}$ & $8.8 \mathrm{a}$ & 0 & 0 & 0 & 0 & 0 & $0 \mathrm{~b}$ & 0 & 0 & $5.6 \mathrm{a}$ & $0.5 \mathrm{a}$ & $3.2 \mathrm{a}$ & $1.7 \mathrm{a}$ \\
\hline & $0-5$ & $2.5 \mathrm{~b}$ & $1.5 \mathrm{~b}$ & $2.5 \mathrm{~b}$ & $4.0 \mathrm{~b}$ & 0 & 0 & 0 & 0.5 & 0 & $0.3 \mathrm{~b}$ & 0 & 0 & $3.2 \mathrm{~b}$ & $0.3 \mathrm{a}$ & $0.5 \mathrm{~b}$ & $\begin{array}{l}1.0 \\
a b\end{array}$ \\
\hline & 5-10 & $1.2 \mathrm{c}$ & $0.7 \mathrm{bc}$ & $\begin{array}{l}1.2 \\
b c\end{array}$ & $3.5 \mathrm{~b}$ & 0 & 0 & 0 & 0 & 0 & $0.3 \mathrm{~b}$ & 0 & 0 & $1.0 \mathrm{c}$ & $0.5 \mathrm{a}$ & $0.2 \mathrm{~b}$ & $\begin{array}{l}1.3 \\
a b\end{array}$ \\
\hline & 10-15 & $1.5 \mathrm{c}$ & $0 \mathrm{c}$ & $0.5 \mathrm{c}$ & $2.7 \mathrm{~b}$ & 0.2 & 0 & 0 & 0.2 & 0 & $4.3 \mathrm{a}$ & 0 & 0 & $0 \mathrm{~d}$ & $0 \mathrm{~b}$ & $0.5 \mathrm{~b}$ & $0.5 \mathrm{c}$ \\
\hline & $15-20$ & $1.0 \mathrm{c}$ & $0 \mathrm{c}$ & $0.5 \mathrm{c}$ & $2.7 \mathrm{~b}$ & 0.2 & 0 & 0 & 0 & 0 & $0 \mathrm{~b}$ & 0 & 0 & $0.8 \mathrm{c}$ & $0 \mathrm{~b}$ & $0.3 \mathrm{~b}$ & $0.2 \mathrm{c}$ \\
\hline
\end{tabular}


The density of EPF in the forest leaf litter varied depending on the sampling date and the type of forest, but the dominant genus was Beauveria. In both Golice and Chodów forests, Beauveria spp. and Lecanicillium spp. were isolated from samples on all sampling dates (Tables 1 and 2). The greatest density of Beauveria spp. in leaf litter occurred in the spring of 2017. We observed an increasing trend of higher densities of Beauveria spp. in leaf litter samples over subsequent sampling dates. The highest density of CFUs of Beauveria spp. fungi, regardless of the date of the study, was observed in the leaf litter collected from the Golice locality, from the mixed forest $\left(10.0 \times 10^{3} \mathrm{CFUs} / \mathrm{g}\right)$, while in the village of Chodów, from the deciduous forest, these fungi produced $13.2 \times 10^{3} \mathrm{CFUs}$ per g leaf litter. Lecanicillium spp. were recovered from leaf litter samples in Golice forestes on all sampling dates, with mean densities ranging from 0.3 to $2.2 \times 10^{3} \mathrm{CFU} / \mathrm{g}$. We found greater densities of Lecanicillium spp. in the leaf litter in Chodów than the leaf litter in Golice (Figures 1 and 2). The fungi from Metarhizium genus were also found in the leaf litter in Golice; the fungi formed CFUs in the first (autumn 2015) study period, in deciduous leaf litter, and in the second study period (spring 2016), in coniferous leaf litter. In deciduous leaf litter collected in spring 2017 from Chodów, apart from Beauveria spp. and Lecanicillium spp., the presence of two more genera of EPF was noted, namely, Cordyceps spp. and Metarhizium spp. Both species produced of $0.2 \times 10^{3} \mathrm{CFUs}$ per g leaf litter.

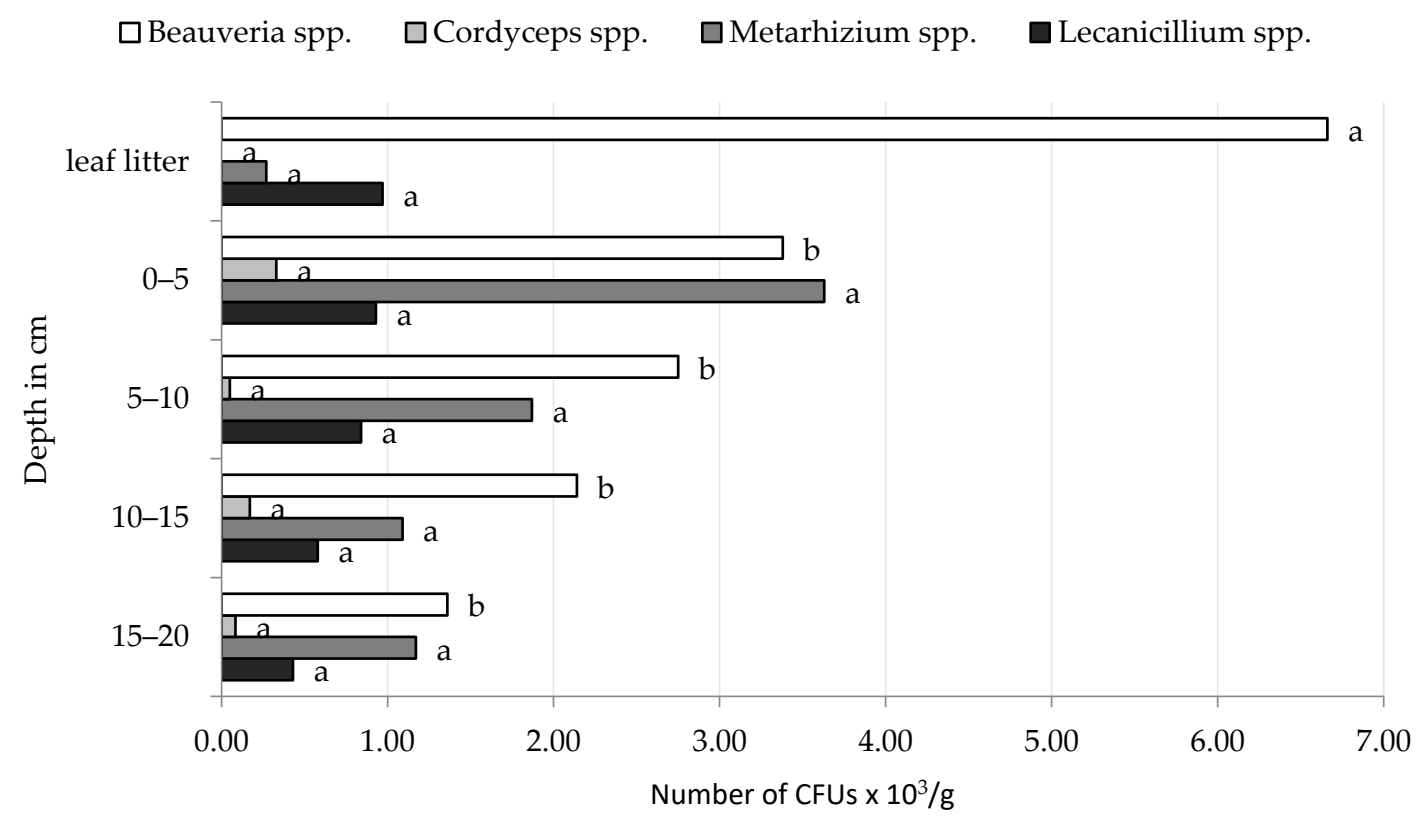

Figure 1. Average density of CFUs of entomopathogenic fungi in the leaf litter and individual layers of forest soils collected in Golice. ${ }^{a b}$ Statistically significant differences between the concentration of CFUs of entomopathogenic fungi depending on the soil depth.

The current study showed that the mean densities of EPF varied by sampling date, soil depth, and forest type (Tables 1 and 2).

The research showed that the Beauveria spp. were most abundant in the top layer of the soil $(0-5 \mathrm{~cm})$, and densities of these fungi gradually decreased deeper into the soil profile (Tables 1 and 2). When analysing the number of CFUs of these fungi, at a soil layer of 0-10 cm, Beauveria spp. in the first two study dates (autumn 2015 and spring 2016) formed at least twice as many CFUs than in the soil layer below $(10-20 \mathrm{~cm})$. In the soils collected in autumn 2016, this difference was several times higher. The largest number of Beauveria spp. was found in a soil layer of $0-5 \mathrm{~cm}$ in autumn 2016 from a deciduous forest located in Chodów; the density was $9.0 \times 10^{3} \mathrm{CFUs} / \mathrm{g}$. Regardless of the type of forest and locality, the smallest number of CFUs of Beauveria spp. was formed in autumn 2015 (Tables 1 and 2; Figures 1 and 2). 


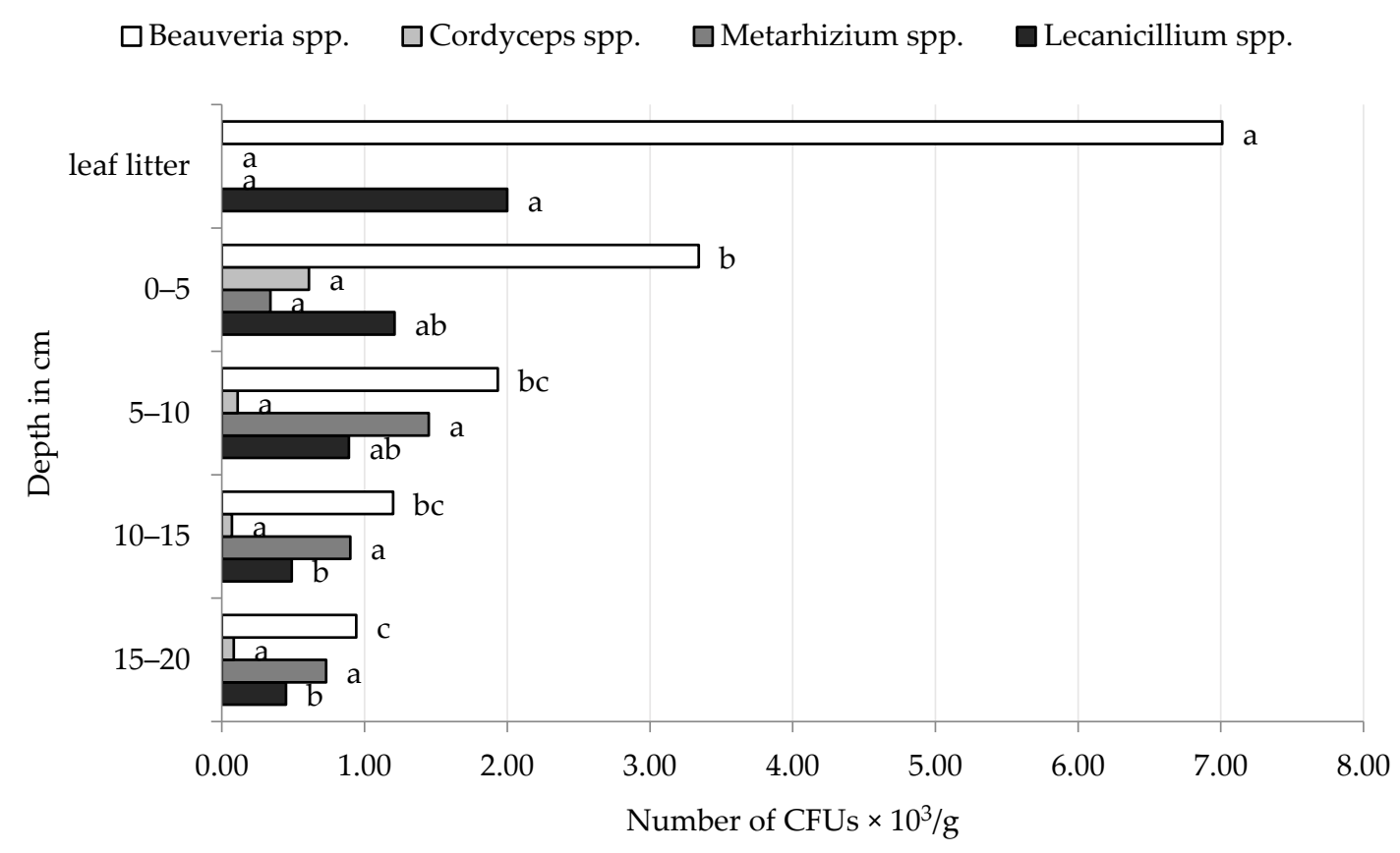

Figure 2. Average density of CFUs of entomopathogenic fungi in the leaf litter and individual layers of forest soils collected in Chodów. abc Statistically significant differences between the concentration of CFUs of entomopathogenic fungi depending on the soil depth.

Second to Beauveria spp., we frequently isolated Lecanicillium spp. from soil samples in both localities. The research showed that the number of CFUs of these fungi in each layer of the studied levels showed a tendency to decrease deeper into the soil profile, with few deviations. The fungi Lecanicillium spp. in the soil layer, lying 0-5 and 5-10 cm under the leaf litter, formed, on average, twice as many CFUs than the fungi in the lower layers (Tables 1 and 2).

The presence of the fungi from the genus Cordyceps was also noted in individual samples of the investigated forest soils. It is worth noting that the presence of CFUs of these fungi was not found in any of the examined soil layers from the pine forest at all four test dates in both localities.

The occurrence and density of Metarhizium fungi varied by forest type and locality. The greatest number of CFUs was formed by these fungi in the soil collected from the coniferous forest in Golice in two study periods (autumn 2015 and spring 2016) in the $0-5 \mathrm{~cm}$ layer, creating $28.8 \times 10^{3}$ and $11.5 \times 10^{3} \mathrm{CFUs} / \mathrm{g}$, respectively. In the layers below, deeper into the soil profile, a tendency of a gradual reduction in the concentration of CFUs of this species was observed (Table 1). In contrast, Metarhizium spp. were most abundant in deeper layers of soil in deciduous forests in Chodów compared to mean CFUs in the top layer (0-5 cm; Table 2, Figure 2).

Among the EPF that were isolated from forested habitats, Beauveria spp. and Lecanicillium spp. were most abundant in leaf litter; their density in soil gradually decreased in deeper soil depths (Figures 1 and 2).

The current study shows that the abundance of EPF varies depending on the time of the study (Figures 3 and 4). The highest densities of Beauveria spp. and Lecanicillium spp. were found in Golice in the spring of 2017, and the greatest abundance of Cordyceps spp. was observed in spring 2016. Metarhizium spp. were most abundant in autumn 2015 compared to other sampling dates (Figure 3). 


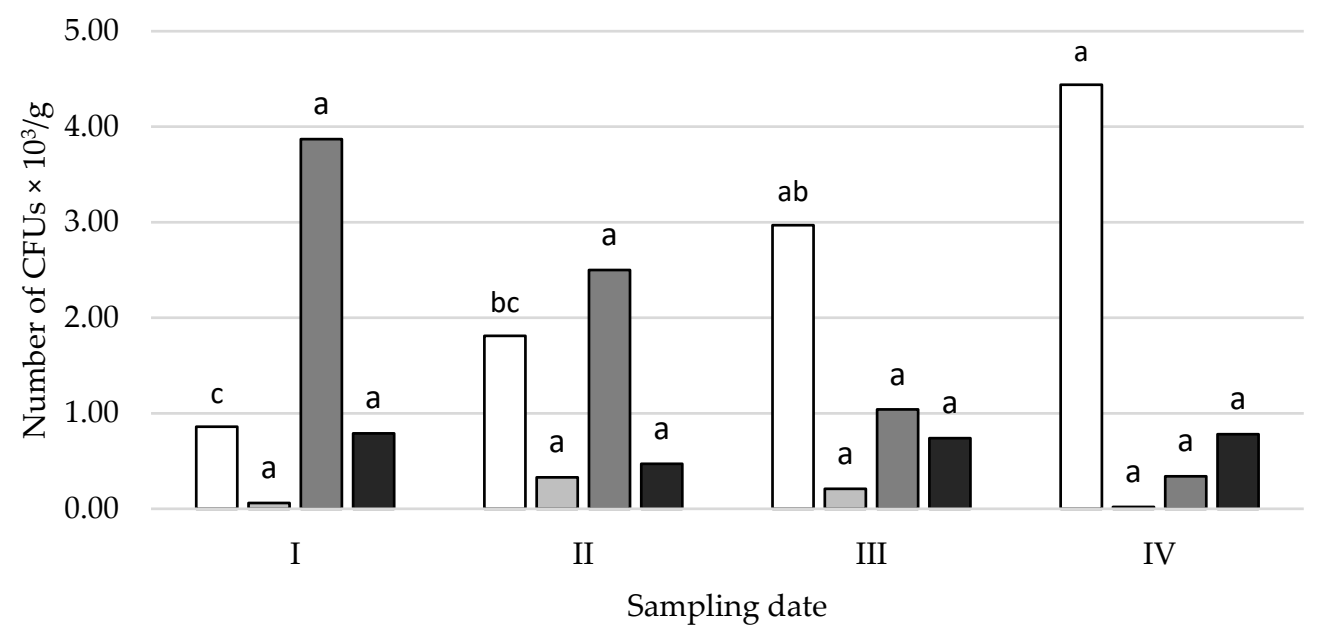

$\square$ Beauveria spp. $\quad \square$ Cordyceps spp. $\quad \square$ Metarhizium spp. $\quad \square$ Lecanicillium spp.

I-autumn 2015; II-spring 2016; III-autumn 2016; IV - spring 2017.

Figure 3. Average density of CFUs of entomopathogenic fungi in forest soils collected in Golice depending on the date of sampling for research. ${ }^{\text {abc }}$ Statistically significant differences between the concentration of CFUs of entomopathogenic fungi in the studied soils and the time of the study.

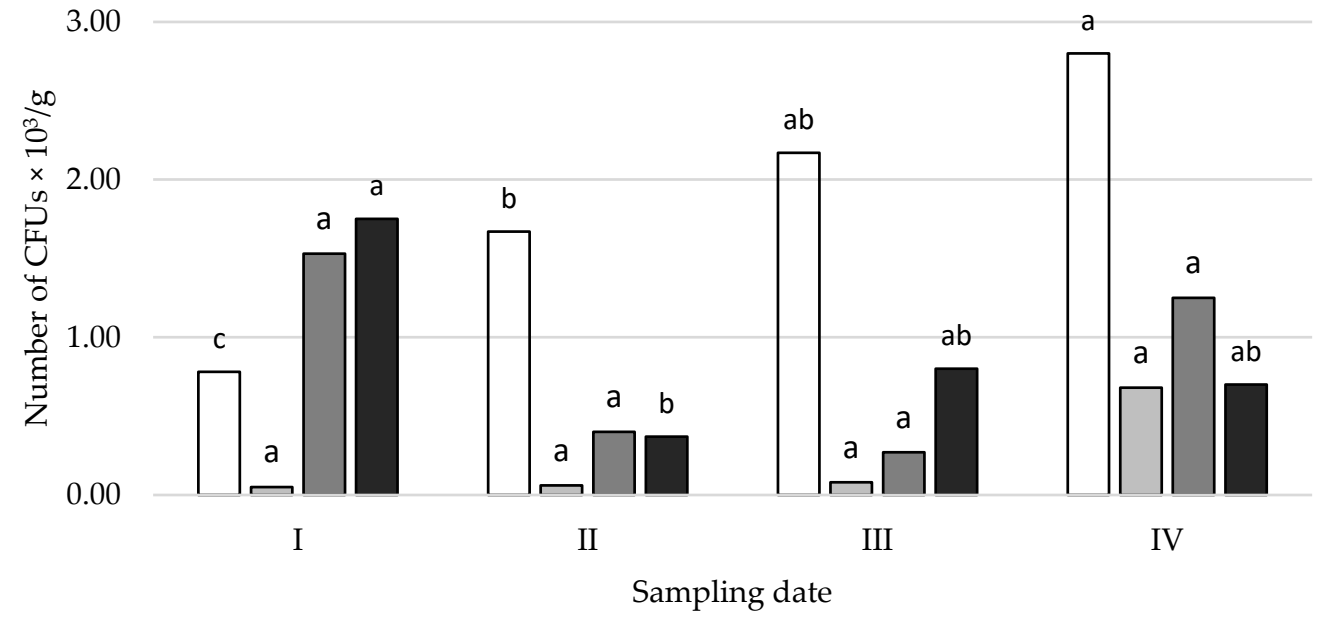

$\square$ Beauveria spp. $\quad \square$ Cordyceps spp. $\quad \square$ Metarhizium spp. $\quad \square$ Lecanicillium spp.

$$
\text { I-autumn 2015; II-spring 2016; III-autumn 2016; IV - spring } 2017 .
$$

Figure 4. Average density of CFUs of entomopathogenic fungi in forest soils collected in Chodów, depending on the date of sampling for research. ${ }^{\text {abc }}$ Statistically significant differences between the concentration of CFUs of entomopathogenic fungi in the studied soils and the time of the study.

In soil samples collected from Chodów, the greatest densities of Beauveria spp. and Cordyceps spp. occurred in spring 2017, whereas the greatest densities of Metarhizium spp. and Lecanicillium spp. were observed in autumn 2015 (Figure 4). The type of environment (coniferous, deciduous and mixed forest), both in Golice and Chodów, did not significantly affect the density of EPF. However, the main effects of sampling date and sample/depth were significant (Figures 1-4). As a result of the analysis of variance, in both locations, the sampling depth and the sampling time significantly affect the number of CFUs of Beauveria 
spp.; in Chodów, this included Lecanicillium spp. These differences were not statistically significant regarding Cordyceps spp. and Metarhizium spp.

\section{Discussion}

The soil environment provides a suitable habitat for insect-pathogenic fungi and other microorganisms since it is protected from UV radiation and buffered against extreme biotic influences [6]. An understanding of the parameters that determine the diversity and distribution of entomopathogenic fungal species in soil would help to identify those species best suited to a particular environment and improve biological control efficacy.

In our research on leaf litter and soil collected from different types of forests in Golice and Chodów, the presence of four genera of EPF was found: Beauveria spp., Cordyceps spp., Metarhizium spp., and Lecanicillium spp. The density of EPF in leaf litter and soil was explained by the time of sampling and the depth of soil samples. Moreover, it was found that the density of EPF was usually higher in leaf litter than in the layers of soil below, and the most frequently isolated fungus from both environments was Beauveria spp. The research carried out as part of this study showed that Beauveria spp. often formed several times more CFUs in leaf litter than in the underlying layers of forest soil. The obtained results confirm the research conducted by Tkaczuk et al. [27], who, carrying out investigations on the density of EPF in three mixed forest habitats in Poland, separately for leaf litter and the soil layer below, found that the fungus B. bassiana dominated in both environments but formed more CFUs in the leaf litter layer than in the soil. Bajan et al. [35], studying leaf litter and soil originating from pine forests in Poland, found that the fungus species that, to the greatest extent, causes the death of the larvae of the trap insect was $B$. bassiana. Tkaczuk [4] and Karg and Bałazy [36] found that forest environments favour the persistence of EPF, and, compared to agroecosystems, forests are more than twice as rich in EPF abundance, with high infectious potential.

The dominance of $B$. bassiana in soils collected from various types of forests is also confirmed by studies conducted in Denmark [37], Finland [7], Poland [27,35,38,39], Japan [40], Italy [41,42] Spain [43,44], Austria [45], Mexico [46], Brasil [47] and Portugal [48]. Niemczyk et al. [21], examining the occurrence of Beauveria spp. in forest soils in Poland, found that this fungus was isolated from a majority of soil samples. As mentioned earlier in the methodology, our research only used morphological methods to determine fungi; this is currently insufficient to differentiate species within the Beauveria, genus [29,32,33], and it is certain that within the isolates of fungi of the genus Beauveria isolated by us on a selective medium, there are several species other than B. bassiana. So far, five Beauveria species, including B. bassiana, B. brongniartii, B. caledonica, B. varroae and B. pseudobassiana, have been documented in Europe [49].

Leaf litter and the soil layer under it are the main reservoirs of EPF in forest environments $[4,25,35,39,50-52]$. Entomopathogenic fungi infecting forest insects can easily survive in leaf litter and on the soil surface, where they have a chance to come into contact, all year round, with hosts that constantly live in the forest floor environment or use them only as a place for pupation or wintering. The periodic or continuous development of EPF in the surface layers of forest soil and leaf litter is, in many cases, a condition for the survival of the species and the spread of pathogens $[14,18,27]$. B. bassiana, in its development cycle, seems to use the strategy, which is referred to by Ewald $[53,54]$ as "sit and wait", which means that the development of the population and the survival of this species in soil or leaf litter depend mainly on repeated host infections over time, and the factors that limit the host population appear to have a major influence on the survival of B. bassiana in the soil environment. The studies of Daousta and Pereira [55] and Steenberg [37] indicate that the continued presence of arthropods in the soil, which are potential B. bassiana hosts, has a significant impact on the survival of this species.

B. bassiana is a fungus often mentioned by many authors as a pathogen of insects temporarily staying or hibernating in the upper layers of forest soil and leaf litter. This species accounted for more than $85 \%$ of the total mortality of Diprion pini L. [39] larvae 
wintering in cocoons and was the most frequently isolated entomopathogen from forest insects in Finland [7]. It should be remembered that leaf litter is an environment very rich in organic matter (Table S2); therefore, one of the concepts explaining the dominance of Beauveria spp. in the layers of litter, rich in organic matter, is the ability of this species to develop in the saprophagous phase $[4,7,8]$.

In the soil environment, EPF show a varying intensity of occurrence depending on the season $[25,56]$; the factors determining their occurrence include temperature and moisture levels [25,56-58]. Bruck and Lewis [59] showed the significant effect of precipitation intensity and, thus, humidity levels on the growth and sporulation of EPF. In the current study, it was observed that the fungi Beauveria spp. produced the fewest CFUs regardless of the type of forest and the locality in autumn 2015. A factor that influenced such results may have been the relatively dry summer and autumn recorded in 2015, when total rainfall was $7.5 \mathrm{~mm}$ in August and $22.8 \mathrm{~mm}$ in October, respectively (Table S1).

The second genus that, apart from Beauveria spp., was the most numerous was Lecanicillium spp. This is the first study to uncover such a high abundance of this fungus in the leaf litter and forest soils in Poland. Entomopathogenic fungi species belonging to the genus Lecanicillium (formerly Verticillium lecanii) have a global distribution, occur on a diverse range of insect species, and have potential for their development as effective biological control agents against a number of plant diseases, insect pests and plant-parasitic nematodes [60]. This entomopathogenic fungus was previously isolated from forest soils in Poland [4,25], China [61], Mexico [62] and India [52].

The current study shows that Metarhizium spp. and Cordyceps spp. occupy forest soils; however, the frequency of their isolation was much lower than that of Beauveria spp. and Lecanicillium spp. M. anisopliae is generally more resistant to agricultural disturbances, and numerous studies have reported that it is significantly more prevalent in cultivated areas than in natural habitats $[8,56,63,64]$. The current study shows that, especially in autumn, in the case of soils from the deciduous and mixed forests in Chodów, the CFU density of the fungi Metarhizium spp. and Cordyceps spp. is sometimes higher in deeper soil layers than in shallow ones. This may be due to the increased activity of insects in the soil environment of forests during summer and autumn and, thus, the transfer of spores and other forms of fungal propagation on their bodies deeper into the soil profile $[65,66]$. In addition, insects that go down to the soil in autumn for the winter diapause become infected and die as a result of fungal infection in the soil at different depths, contributing significantly to its enrichment with infectious material. According to Sosnowska et al. [67], such mycoses of various insects overwintering in the soil of deciduous and mixed forest habitats of the Białowieża Primeval Forest (Poland) are mainly caused by fungi of the genus Cordyceps, and epizootics caused by these fungi are often observed in autumn.

Popowska-Nowak et al. [25], who conducted research in various regions of Poland, showed that M. anisopliae and I. fumosorosea (Cordyceps fumosorosea) were the most frequently isolated species of entomopathogenic fungi from the soils of several-year-old forest nurseries, especially in the springtime, which, according to the authors, was associated with the higher humidity of the soil environment. Different research results by other authors may result from the fact that the species composition and the intensity of the occurrence of EPF in the soil are influenced by many factors, such as the content of organic matter, $\mathrm{pH}$, soil type and method of its cultivation [7-9,21,47,48,68,69], as well as microclimatic conditions (temperature, humidity) and potential host density [36,68]. It could also be related to the methods of quantifying EPF abundance. Two methods are generally used to detect EPF in soil: (1) Bait methods use Galleria mellonella L. (Lepidoptera: Pyralidae) or other insects $[46,70]$ and are relatively simple and sensitive but provide rather semiquantitative data [71-73]; (2) plating methods using various selective media [22,40,74-76] that are particularly useful when quantification is necessary or when the input material is not soil (e.g., air and some plant parts). Bueno-Pallero et al. [48] observed different patterns of EPF occurrence by using different isolation methods, particularly between insect baits and selective medium methodology. The use of selective media resulted in higher recoveries 
of EPF than either soil-baiting method. Since the aim of our research was to accurately quantify the density of fungal inoculum in individual samples of soil and leaf litter, we applied the selective medium developed by Strasser et al. [22].

The current study shows that the number of CFUs of EPF in soil from various types of forests is, in most cases, higher in the top layer of soil $(0-5$ and $5-10 \mathrm{~cm})$, located directly under the leaf litter, and gradually decreased deeper into the soil profile. This is confirmed by the research of Tkaczuk [4], who stated that, especially in spring, in the case of forest and meadow habitats and arable fields, the highest CFUs of EPF are located in the surface layers of the soil profile $(0-5 \mathrm{~cm})$ and, relatively lower, at deeper depths $(15-20 \mathrm{~cm})$. A similar pattern was observed in autumn regarding permanent habitats such as meadows and forests. The above structure of the distribution of EPF in the soil profile in the case of meadow and forest habitats, which was also confirmed in our research, results from the stability of these environments, which, unlike arable fields, are not subjected to disturbances from farming practices.

According to Tkaczuk [4], in the soil collected in autumn from the deeper layers $(15-20 \mathrm{~cm})$ of cultivated fields, more CFUs were found in $1 \mathrm{~g}$ of soil than in the surface layer $(0-5 \mathrm{~cm})$, which is certainly the result of soil mixing and, thus, displacement of the infection material from the soil layers to the deepest level as a result of autumn cultivation, especially ploughing. According to Dighton et al. [77], the movement of soil as a result of tillage operations (ploughing, use of a disc harrow) may contribute to increased dispersion of soil microorganisms in the arable soil layer $(20-30 \mathrm{~cm})$ as well as horizontal dispersion into its deeper levels.

\section{Conclusions}

Knowledge of the composition and distribution of native entomopathogenic fungal species is essential to evaluate the potential of biological control in a given ecosystem. As part of this study, a comparative assessment of the occurrence of EPF was carried out separately for the environment of leaf litter and the forest soil directly below it in three different types of forest for the first time on a large scale. Beauveria spp., Cordyceps spp., Metarhizium spp., and Lecanicillium spp. were found in the soil and leaf litter of the investigated forests. The conducted research showed that the density of CFUs of EPF was usually higher in leaf litter than in the layers of soil below, and the most frequently isolated fungi from both environments were Beauveria spp. The second fungal genus that, apart from Beauveria spp., was the most abundant in Polish forests was Lecanicillium spp. The current research will give new insight into the understanding of EPF distribution and persistence in the forest underground environment and their biodiversity conservation.

Supplementary Materials: The following are available online at https:/ /www.mdpi.com/2075-445 0/12/2/134/s1, Figure S1: Location of sampling for testing; Table S1: Average values of temperature and precipitation in 2015-2017 (Siedlce district); Table S2: The $\mathrm{pH}$ value and the content of organic matter in the forest litter and soil samples (average value from the $0-20 \mathrm{~cm}$ layer) of the studied forest types.

Author Contributions: Conceptualisation, A.M.-S. and C.T.; writing—original draft preparation, A.M.-S. and C.T.; writing-review and editing, A.M.-S. and C.T. All authors have read and agreed to the published version of the manuscript.

Funding: The results of the research carried out under research theme No. 44/20/B were financed by a science grant from the Ministry of Science and Higher Education.

Institutional Review Board Statement: Not applicable

Informed Consent Statement: Not applicable

Data Availability Statement: The data presented in this study are available in the article and Supplementary Materials provided.

Conflicts of Interest: The authors declare no conflict of interest. 


\section{References}

1. Ciesielska, K.; Ciesielski, M. Forest cover in Poland in territorial sections. Wiadomości Statystyczne 2017, 5, 62-78. [CrossRef]

2. Report on the State of Forests in Poland 2016; CILP: Warsaw, Poland, 2017.

3. Głowacka, B. Methodology of Integrated Protection of Coniferous Stands. In The Work Was Commissioned by the Directorate General of State Forests; Instytut Badawczy Leśnictwa w Sękocinie: Sękocin Nowy, Poland, 2013. (In Polish)

4. Tkaczuk, C. Occurrence and Infective Potential of Entomopathogenic Fungi in Soils of Agrocenoses and Seminatural Habitats in the Agricultural Landscape; Scientific Dissertation no. 94; Wydawnictwo Akademii Podlaskiej: Siedlce, Poland, 2008; p. 160. (In Polish)

5. Galus-Barchan, A.; Paśmionka, I. The occurrence of selected microorganisms in the soil under forest with particular reference to mould fungi. Polish J. Agron. 2014, 17, 11-17.

6. Keller, S.; Zimmermann, G. Mycopathogens of soil insects. In Insect-Fungus Interactions; Wilding, N., Collins, N.M., Hammond, P.M., Webber, J.F., Eds.; Academic Press: London, UK, 1989; pp. 239-270.

7. Vänninen, I. Distribution and occurrence of four entomopatogenic fungi in Finland: Effect of geographical location, habitat type and soil type. Mycol. Res. 1996, 100, 93-101. [CrossRef]

8. Quesada-Moraga, E.; Navas-Cortés, J.A.; Maranhao, E.A.A.; Ortiz-Urquiza, A.; Santiago-Álvarez, C. Factors affecting the occurrence and distribution of entomopathogenic fungi in natural and cultivated soils. Mycol. Res. 2007, 111, 947-966. [CrossRef]

9. Madeo, J.; Cagan, L. Factors affecting the occurrence of entomopathogenic fungi in soils of Slovakia as reveled using two methods. Biol. Control. 2011, 59, 200-208.

10. Meyling, N.V.; Thorup-Kristensen, K.; Eilenberg, J. Below- and aboveground abundance and distribution of fungal entomopathogenus in experimental conventional and organic cropping systems. Biol. Control 2011, 59, 180-186. [CrossRef]

11. Niu, X.; Xie, W.; Zhang, J.; Hu, Q. Biodiversity of entomopathogenic fungi in the soils of South China. Microorganisms 2019, 7, 311. [CrossRef]

12. Jackson, T.A.; Alves, S.B.; Pereira, R.M. Success in biological control of soil-dwelling insects by pathogens and nematodes. In Biological Control: Measures of Success; Gurr, G., Wratten, S., Eds.; Kluwer Academic Publisher: Dordrecht, The Netherlands, 2000; pp. 271-296.

13. Zimmermann, G. The entomopathogenic fungi Isaria farinosa (formerly Paecilomyces farinosus) and the Isaria fumosorosea species complex (formerly Paecilomyces fumosoroseus): Biology, ecology and use in biological control. Biocontrol Sci. Technol. 2008, 18, 865-901. [CrossRef]

14. Augustyniak-Kram, A.; Kram, K.J. Entomopathogenic fungi as an important natural regulator of insect outbreaks in forest (Review). In Forest Ecosystem- More Than Just Trees; Blanco, J.A., Lo, Y.-H., Eds.; InTech: Rijeka, Croatia, 2012; pp. 265-294.

15. Tkaczuk, C.; Król, A.; Majchrowska-Safaryan, A.; Niecewicz, Ł. The occurrence of entomopathogenic fungi in soils from fields cultivated in a conventional and organic system. J. Ecol. Eng. 2014, 15, 137-144.

16. Gaugler, R. Ecological consideration in the biological control of soil-inhabiting insects with entomopathogenic nematodes. Agric. Ecosyst. Environ. 1988, 24, 351-360. [CrossRef]

17. Bałazy, S. Diversity of entomopathogenic fungi in agricultural landscapes of Poland and France. In Ecological Management of Countryside in Poland and France; Ryszkowski, L., Wicherek, S., Eds.; Research Centre for Agricultural and Forest Environment, Polish Academy of Sciences: Poznań, Poland, 1997; pp. 101-111.

18. Bałazy, S. Significance of protected areas for the preservation of entomopathogenic fungi. Kosmos 2004, 53, 5-16. (In Polish)

19. Dara, S.K.; Motlava, C.; Barta, M. Microbial control of invasive forest pests with entomopathogenic fungi: A review of the current situation. Insects 2019, 10, 341. [CrossRef] [PubMed]

20. Kovač, M.; Gorczak, M.; Wrzosek, M.; Tkaczuk, C.; Pernek, M. Identification of entomopathogenic fungi as naturally occurring enemies of the invasive oak lace bug, Corythucha arcuata (Say) (Hemiptera: Tingidae). Insects 2020, 11, 679. [CrossRef] [PubMed]

21. Niemczyk, M.; Sierpińska, A.; Treba, A.; Sokołowski, K.; Przybylski, P. Natural occurrence of Beauveria spp. In outbreak areas of cockchafers (Melolontha spp.) in forest soils from Poland. BioControl 2019, 64, 159-172. [CrossRef]

22. Strasser, H.; Forrer, A.; Schinner, F. Development of media for the selective isolation and maintenance of virulence of Beauveria brongniartii. In Microbial Control of Soil Dwelling Pests; Jackson, T.A., Glare, T.R., Eds.; AgResearch: Lincoln, New Zeland, 1996; pp. 125-130.

23. Keller, S.; Kessler, P.; Schweizer, C. Distribution of insect pathogenic soil fungi in Switzerland with special reference to Beauveria brongniartii and Metarhizium anisopliae. BioControl 2003, 48, 307-319. [CrossRef]

24. Meyling, N.V.; Lubeck, M.; Buckley, E.P.; Eilenberg, J.; Rehner, S.A. Community composition, host range and genetic structure of the fungal entomopathogen Beauveria in adjoining agricultural and seminatural habitats. Mycol. Ecol. 2009, 18, 1282-1293.

25. Popowska-Nowak, E.; Skrzecz, I.; Tumialis, D.; Pezowicz, E.; Samborska, I.; Góral, K. Entomopathogenic fungi in the soils of forest plantations: Towards the control of large pine weevil, Hylobius abietis. Balt. For. 2016, 22, 8-15.

26. Tkaczuk, C.; Tipping, C.; Majchrowska-Safaryan, A.; Król, A.; Wyrzykowska, M.; Wegensteiner, R. The occurrence of entomopathogenic fungi in soils from apple orchards protected in different farming systems. Fresen. Environ. Bull. 2019, 28, 7906-7914.

27. Tkaczuk, C.; Majchrowska-Safaryan, A.; Harasimiuk, M. The occurrence and infective potential of entomopathogenic fungi in the soil of arable fields, meadows and forest habitats. Prog. Plant Prot. 2016, 56, 5-11. (In Polish)

28. Rehner, S.A.; Buckley, E.P. A Beauveria phylogeny inferred from nuclear ITS and EF1- $\alpha$ sequences: Evidence for cryptic diversification and links to Cordyceps teleomorphs. Mycologia 2005, 97, 84-98. [CrossRef] 
29. Rehner, S.A.; Minnis, A.M.; Sung, G.H.; Luangsa-ard, J.J.; Devotto, L.; Humber, R.A. Phylogeny and systematics of the anamorphic, entomopathogenic genus Beauveria. Mycologia 2011, 103, 1055-1073. [CrossRef] [PubMed]

30. Humber, R.A. Manual of Techniques in Invertebrate Pathology. In Identification of Entomopathogenic Fungi; Lacey, L.A., Ed.; Academic Press: London, UK, 2012; pp. 151-187.

31. Inglis, G.D.; Enkerli, J.; Goettel, M.S. Manual of Techniques in Invertebrate Pathology. In Laboratory Techniques Used for Entomopathogenic Fungi: Hypocreales Chapter VII; Lacey, L.A., Ed.; Academic Press: London, UK, 2012; pp. 189-253.

32. Bischoff, J.F.; Rehner, S.A.; Humber, R.A. Metarhizium frigidum sp. nov.: A cryptic species of M. anisopliae and member of the M. flavoviride complex. Mycologia 2006, 98, 737-745. [CrossRef] [PubMed]

33. Bischoff, J.F.; Rehner, S.A.; Humber, R.A. A multilocus phylogeny of the Metarhizium anisopliae lineage. Mycologia 2009, 101, 508-528. [CrossRef] [PubMed]

34. Kepler, R.M.; Luangsa-ard, J.J.; Hywel-Jones, N.L.; Quandt, C.A.; Sung, G.H.; Rehner, S.A.; Aime, M.C.; Henkel, T.W.; Sanjuan, T.; Zare, R.; et al. A phylogenetically-based nomenclature for Cordycipitaceae (Hypocreales). IMA Fungus 2017, 8, 335-353. [CrossRef]

35. Bajan, C.; Kmitowa, K.; Mierzejewska, E.; Popowska-Nowak, E.; Miętkiewski, R.; Górski, R.; Miętkiewska, Z.; Głowacka, B. The occurrence of entomopathogenic fungi in the bedding and soil of pine woods in the gradient of the forest environment pollution. Prace IBL Ser. B 1995, 24, 87-97. (In Polish)

36. Karg, J.; Balazy, S. The influence of landscape structure on the incidence of pests and their antagonists in agricultural crops. Prog. Plant Prot. 2009, 49, 1015-1034. (In Polish)

37. Steenberg, T. Natural Occurrence of Beauveria bassiana (Bals.) Vuill. with Focus on Infectivity to Sitona Species and Other Insects in Lucerne. Ph.D. Thesis, Royal Veterinary and Agricultural University, Copenhagen, Denmark, 1995.

38. Miętkiewski, R.; Dzięgielewska, M.; Janowicz, K. Entomopathogenic fungi isolated in the vicinity of Szczecin. Acta Myc. 1998, $33,12-134$.

39. Tkaczuk, C.; Miętkiewski, R. Mycoses of pine sawfly (Diprion pini L.) during hibernation period in relation to entomopathogenic fungi occurring in soil and litter. Fol. Forest. Pol. Ser. A For. 1998, 40, $26-32$.

40. Shimazu, M.; Sato, H.; Maehara, N. Density of the entomopathogenic fungus, Beauveria bassiana Vuillemin (Deuteromycotina: Hyphomycetes) in forest air and soil. Appl. Entomol. Zool. 2002, 37, 19-26. [CrossRef]

41. Tarasco, E.; Bievre, C.; Papierok, B.; Poliseno, M.; Triggiani, O. Occurrence of entomopathogenic fungi in soils in Southern Italy. Entomol. Bari 1997, 31, 157-166.

42. Tkaczuk, C.; Renella, G. Occurrence of entomopathogenic fungi in soils from Central Italy under different management. IOBC/WPRS Bull. 2003, 26, 85-89.

43. Asensio, L.; Carbonell, T.; Lopez-Jimenez, J.A.; Lopez-Llorca, L.V. Entomopathogenic fungi in soils from Alicante province. Span. J. Agric. Res. 2003, 1, 37-45. [CrossRef]

44. Maranhão, E.A.A.; Santiago-Alvarez, C. Occurrence of entomopathogenic fungi in soils from different parts of Spain. IOBC/WPRS Bull. 2003, 26, 59-62.

45. Tkaczuk, C.; Bałazy, S.; Krzyczkowski, T.; Wegensteiner, R. Extended studies on the diversity of arthropod-pathogenic fungi in Austria and Poland. Acta Mycol. 2011, 46, 211-222. [CrossRef]

46. Sánchez-Peña, S.R.; San-Juan Lara, J.; Medina, R.F. Occurrence of entomopathogenic fungi from agricultural and natural ecosystems in Saltillo, México, and their virulence towards thrips and whiteflies. J. Insect. Sci. 2011, 11, 1. [CrossRef] [PubMed]

47. Mora, M.A.E.; Rouws, J.R.C.; Fraga, M.E. Occurrence of entomopathogenic fungi in Atlantic forest soils. Microbiol. Discov. 2016, 4, 1-7. [CrossRef]

48. Bueno-Pallero, F.A.; Blanco-Pérez, R.; Vicente-Díez, I.; Rodríguez Martín, J.A.; Dionísio, L.; Campos-Herrera, R. Patterns of occurrence and activity of entomopathogenic fungi in the Algarve (Portugal) using different isolation methods. Insects 2020, 11, 352. [CrossRef] [PubMed]

49. Barta, M.; Horáková, M.K.M.; Georgieva, M.; Mirchev, P.; Zaemdzhikova, G.; Pilarska, D.; Takov, D.; Todorov, M.; Hubenov, Z.; Pilarski, P.; et al. Entomopathogenic fungi (Ascomycota: Hypocreales) as natural antagonists of the pine processionary moth Thaumetopoea pityocampa (Denis \& Schiffermüller, 1775) (Lepidoptera: Notodontidae) in Bulgaria. Acta Zool. Bulg. 2020, 15, 89-96.

50. Świeżyńska, H.; Górnaś, E. Entomopathogenic fungi on some species of boronidae (Hymenoptera: Diprionidea) in the years 1971-1975. Sylwan 1976, 8, 47-56. (In Polish)

51. Bałazy, S. Entomopathogenic fungi and their significance for plant protection programmes). In Protection of the Agricultural Environment in the Light of the Agri-Environmental Programs of the European Union; Bałazy, S., Gmiat, A., Eds.; Brzesko-Poznan-Turew: Poznań, Poland, 2007; pp. 118-126.

52. Vivekanandhan, P.; Bedini, S.; Shivakumar, M.S. Isolation and identification entomopathogenic fungus from Estern Ghats of South Indiana forest soil and their efficacy as biopesticides from mosquito control. Parasitol. Int. 2020, 76, 1-27. [CrossRef]

53. Ewald, P.W. Host parasite relations, vectors, and the evolution of disease severity. Annu. Rev. Ecol. Syst. 1983, 14, 465-485. [CrossRef]

54. Ewald, P.W. The evolution of virulence: A unifying link between parasitology and ecology. J. Parasitol. 1995, 81, 659-669. [CrossRef]

55. Daoust, R.A.; Pereira, R.M. Survival of Beauveria bassiana (Deuteromycetes: Moniliales) conidia on cadavers of cowpea pests stored outdoors and in laboratory Brazil. Environ. Entomol. 1986, 15, 642-647. [CrossRef] 
56. Sun, B.D.; Yu, H.Y.; Chen, A.J.; Liu, X.Z. Insect-associated fungi in soils of field crops and orchards. Crop Prot. 2008, 27, 1421-1426. [CrossRef]

57. Inglis, G.D.; Goettel, M.S.; Butt, T.M.; Strasser, H. Use of hyphomycetous fungi for managing insect pests: Fungi as Biocontrol Agents. In Progress, Problems and Potential; Butt, T.M., Jackson, C., Magan, N., Eds.; CABI Publishing: Wallingford, UK, 2001; pp. 23-69.

58. Wyrebek, M.; Huber, C.; Sasan, R.K.; Bidochka, M.J. Three sympatrically occurring species of Metarhizium show plant rhizosphere specificity. Microbiology 2011, 157, 2904-2911. [CrossRef]

59. Bruck, D.J.; Lewis, L.C. Rainfall and crop residue effects on soil dispersion and Beauveria bassiana spread to corn. Appl. Soil Ecol. 2002, 20, 183-190. [CrossRef]

60. Goettel, M.S.; Koike, M.; Kim, J.J.; Aiuchi, D.; Shinya, R.; Brodeur, J. Potential of Lecanicillium spp. for management of insects, nematodes and plant diseases. J. Invertebr. Pathol. 2008, 98, 256-261. [CrossRef] [PubMed]

61. Sun, B.D.; Liu, X.Z. Occurrence and diversity of insect-associated fungi in natural soils in China. Appl. Soil Ecol. 2008, 39, 100-108. [CrossRef]

62. Gonazález-Baca, G.; Vargas-Madriz, H.; Acuña-Soto, J.A.; Gonazález-Gaona, O.J.; Lázaro-Dzul, M.O.; Azuara-Dominauez, A. Distribution of entomopathogenic fungi in cultivated and noncultivated soils in Southern Tamaulipas, Mexico. Southwest. Entomol. 2019, 44, 139-142. [CrossRef]

63. Bidochka, M.J.; Kasperski, J.E.; Wild, G.A.M. Occurrence of the entomopathogenic fungi Metarhizium anisopliae and Beauveria bassiana in soils from temperate and near-northern habitats. Can. J. Bot. 1998, 76, 1198-1204.

64. Hummel, R.L.; Walgenbach, J.F.; Barbercheck, M.E.; Kennedy, G.G.; Hoyt, G.D.; Arellano, C. Effects of production practices on soil-borne entomopathogens in western North Carolina vegetable systems. Environ. Entomol. 2002, 31, 84-91. [CrossRef]

65. Hajek, A.E. Ecology of terrestrial fungal entomopathogens. Adv. Microb. Ecol. 1997, 15, 193-249.

66. Dromph, K.M. Collembolans as vectors of entomopathogenic fungi. Pedobiologia 2003, 47, 245-256. [CrossRef]

67. Sosnowska, D.; Bałazy, S.; Prishchepa, L.; Mikulskaya, N. Biodiversity of arthropod pathogens in the Białowieża forest. J. Plant Protect. Res. 2004, 44, 313-321.

68. Walstad, J.D.; Anderson, R.F.; Stambaugh, W.J. Effects of environmental conditions on two species of muscardine fungi (Beauveria bassiana and Metarhizium anisopliae). J. Invertebr. Pathol. 1970, 2, 221-226. [CrossRef]

69. Bouamama, N.; Vidal, C.; Fargues, J. Effects of fluctuating moisture and temperature regimes on the persistence of quiescent conidia of Isaria fumosorosea. J. Invertebr. Pathol. 2010, 105, 139-144. [CrossRef]

70. Sharma, L.; Oliveira, I.; Torres, L.; Marques, G. Entomopathogenic fungi in Portuguese vineyards soils: Suggesting a 'GalleriaTenebrio-bait method' as bait insects Galleria and Tenebrio significantly underestimate the respective recoveries of Metarhizium (robertsii) and Beauveria (bassiana). MycoKeys 2018, 38, 1-23. [CrossRef]

71. Zimmermann, G. Galleria bait method for detection of entomopathogenic fungi in soil. J. App. Entomol. 1986, 2, $213-215$. [CrossRef]

72. Vega, F.E.; Dowd, P.F.; Lacey, L.A.; Pell, J.K.; Jackson, D.M.; Klein, M.G. Dissemination of beneficial microbial agents by insects. In Field Manual of Techniques in Invertebrate Pathology; Lacey, L.A., Kaya, H.K., Eds.; Academic Press: Dordrecht, The Netherland, 2007; pp. 153-177.

73. Jaronski, S.T. Soil ecology of the entomopathogenic ascomycetes: A critical examination of what we (think) we know. In Use of Entomopathogenic Fungi in Biological Pest Management; Research Signpost: Trivandrum, Kerala India, 2007; pp. 91-144.

74. Dobersky, J.W.; Tribe, H.T. Isolation of entomogenous fungi from elm bark and soil with reference to ecology of Beauveria bassiana and Metarhizium anisopliae. Trans. Br. Mycol. Soc. 1980, 74, 95-100. [CrossRef]

75. Liu, Z.Y.; Milner, R.J.; McRae, C.F.; Lutton, G.G. The use of dodine in selective media for the isolation of Metarhizium spp. from soil. J. Invertebr. Pathol. 1993, 62, 248-251. [CrossRef]

76. Fernandes, E.K.K.; Keyser, C.A.; Rangel, D.E.N.; Foster, R.N.; Roberts, D.W. CTC medium: A novel dodine- free selective medium for isolating entomopathogenic fungi, especially Metarhizium acridum, from soil. Biol. Control 2010, 54, 197-205. [CrossRef]

77. Dighton, J.; Jones, H.E.; Robinson, C.H.; Beckett, J. The role of abiotic factors, cultivation practices and soil fauna in the dispersal of genetically modified microorganisms in soils. Appl. Soil Ecol. 1997, 5, 109-131. [CrossRef] 